\title{
THE ACTUALITY OF SOME PRINCIPLES AND IDEAS OF LAW PHILOSOPHY ISSUED BY MIRCEA DJUVARA
}

\author{
Professor Marţian Iovan PhD \\ „Vasile Goldiş" Western University of Arad \\ E-mail: iovanm@uvvg.ro
}

(Received: February 2018; Accepted: May 2018)

\begin{abstract}
The author analyzes in this paper principles and ides of philosophy of law issued by Mircea Djuvara, which preserve their contemporaneity, being useful for the perfecting of the state institutions and of the democracy not only at national level, but also at European Union one. His ideas and logical demonstration on the rational fundamentals of law, the autonomy of the moral and legal conscience, the specificity of truth and of juridical knowledge, the philosophical substantiation of power and Constitution, the principles of the democracy and the connections between the political power and the law are just few of the original elements due to which Djuvara became an acknowledged and respected personality not only in Romania, but also in the experts clubs of the Europe between the two World Wars.
\end{abstract}

Key words: philosophy of law, $20^{\text {th }}$ century, Mircea Djuvara, fundamentals of law.

\section{Introduction}

The philosophical considerations upon law, governing, law-making, justice and equity in Romania occurred and were developed in tight connection with the dynamics of the State institutions and of the law. Systematic writings in this were published in the $19^{\text {th }}$ century starting with the Transylvanian School representatives (especially with Samuil Micu's works), continuing with works issued by scholars such as Simion Bărnuţiu, Timotei Cipariu, Titu Maiorescu, Teodor Păcăţeanu, Em. Antonescu and others. Their concerns focused on philosophical subject such as: the purpose of law, the idea of law, the fundamentals of law, the juridical values, evolutionism and solidarism in law, what is the Encyclopedia of the Law? etc. Other theoreticians of the beginning of the $20^{\text {th }}$ century (G. Drăgănescu, A. Vălimărescu, D. Drăghicescu, Iorgu Radu etc.) extended the theme register of the philosophical consideration on the law rendering obvious the connection to the European spirit, to the juridical encyclopedia. There proliferated in this regard the philosophical reflections on the Encyclopedia of Law, on juridical pragmatism, the relations between the law and the social dynamics, with the morals and religion, with the great ideologies of the first half of the century - as sources of law, the limits of the juridical positivism, the factors of the evolution of the juridical order, the a priori status of the law principles, the State and the idea of justice, the juridical logics and methodology, the juridical ontology, the philosophical fundaments of the international law etc. However, as Nicolae Bagdasar wrote: "the 
philosophy of the law is established as subject in our country by the philosophical works written by Mircea Djuvara (The University of Bucharest) and Eugeniu Speranţia (The University Cluj). [1] During the two world wars, they brought contributions of European value to the development of the philosophy of the law and the juridical culture overall. Analyzing Djuvara's philosophical works, Giorgio del Vecchio concluded that, despite his new Kantian philosophical training, M. Djuvara performed a thorough and original analysis of the reality of the living law and, thus, he has to be acknowledged as the greatest Romanian thinker in the field and also as "one of the greatest contemporary thinkers in the field of the juridical philosophy." [2] In the same order of ideas, expressing his regret that the philosophy of law has been an ignored field of culture in the Romanian world for too long, Eugeniu Speranţia was to write during the years of the second world war that "we have to realize that one cannot speak of a national culture to raise at the level of the greatest Western cultures as long as there is lacking in the soul life concerto the process of discipline and harmony which only the philosophical thinking could bring. The lack of the philosophical spirit in a country may bring opportunism in policy and incoherency in the law drafting process. Under such terms, each line wrote in Romanian and by Romanians in the philosophical field must be welcomed with joy as being one of the starting points for the paths to reaching the end." [3] We aim to analyze in this study few of professor's M. Djuvara scientific ideas and merits, focusing ourselves on the analysis of his ideas on the law matters and on the use of the law philosophy, on the epistemological fundamentals of the law, on the nature and specificity of the juridical knowledge, on aspects of the juridical norms identity in their relation with the idea of justice and equity.

\section{Career, work, the matters of law and the usefulness of the law philosophy}

Mircea Djuvara was born in Bucharest, in 1886. He studies philosophy, law and philology at the University of Bucharest. He followed his studies at Sorbonne, being also interested in psychology, sociology, mathematics, and medicine. In 1913, he acquired the title of doctor in law at Sorbonne with the dissertation "Le fondement du phénomene juridique. Quelques réflexions sur les principles logiques de la connaissance juridique" - Some Considerations on the Logical Principles of the Juridical Knowledge. After World War I, he became professor at the Faculty of Law of Bucharest; he was minister of justice in 1936, he became Minister Secretary of State, Corresponding Member of the Romanian Academy, professor at the Academy of International Law of Hague, vice-president of the International Institute of Law Philosophy and Juridical Sociology of Paris, he established the Romanian Institute of Law Philosophy. 
His scientific and philosophical work consists of 144 titles [4], among which more than one third indicate topics of juridical philosophy. There can be quoted among the last ones: The Kantian Concept of Law (1927); The Difference between Juridical and Political (1928); The Juridical Structure of the Modern Capitalism (1929); Methodological Observations on the Juridical Phenomenon (1929); The General Theory of Law, 3 tomes (1930); The Philosophy of Law: Contemporary Doctrines (1932); The Nature of Law (1933); Rational Law, Sources and Positive Law (1934); The Fundamental Matter of Law (1937); On the Autonomy of the Moral and Juridical Knowledge (1938); Considerations of the Rational Character of the Juridical Realities (1938); The Analysis on the Idea of Convention in Law (1939); Compendium of Juridical Philosophy (1941); Contribution to the Theory of Juridical Knowledge (1942) etc. All these titles are relevant for circumscribing and evaluating this thinker's area of concern in the philosophy of law.

As professor at the Department of Law Encyclopedia and Philosophy of the Academy of International Law of Hague, he had lectures at schools of law of most European capitals gathering a huge prestige, being appreciated in the expert clubs as one of the most imposing personalities in the European philosophy of Law between the two World Wars. Mircea Djuvara was aware that the will of justice and the fight for law involves each and everyone's participation, as citizen, in the political life; therefore, he enrolled in the National Liberal Party, imposing himself by honesty and intelligence, by moral rightfulness, by rejecting the political transactions. His philosophical culture, in general, and the juridical one in particular were a good guide in that regard. As minister of justice, as vice-president of the Chamber of Deputies, he did not deviate from his credo in the supremacy of Law for the adjustment of the human behaviors.

His main source of inspiration, Mircea Djuvara's way of thinking originates from Kant's philosophy. His interest in philosophy in general, and in the philosophy of law in particular has developed since his academic studies under the spell which Titu Maiorescu had on him as professor who knew how to present the theoretical beauty of the philosophical matters often occurring during the lecture of positive juridical texts. There could be seen the premises for Mircea Djuvara's choice for his doctoral dissertation topic which of course was in the scope of the juridical philosophy. The main characteristics of Mircea Djuvara's philosophical attitude was that he considered that the specific matters of the philosophy of law cannot be solved without an overall epistemological and philosophical design; this, as the philosophy of law is part of the philosophy overall. In this regard, Mircea Djuvara wrote that "the philosophy of the law is one of the elements necessary for a genuine culture. Those claiming to have juridical culture cannot lack of it."[5] Among the most important issues of the philosophy of law, there have to be listed those related to the fundamentals of the law, its essence and specificity in relation with other 
domains of the human activity, the goals of the law, the contents and specificity of the juridical knowledge. Solving such matters requires to go beyond any "purely technical" analysis of the law, of the law texts as the juridical sciences are not autonomous subjects - regarding their principles, they rely on an integral totalizing concept which is the general philosophy. The analysis of the theories aiming for the structure, dynamics, goals of the law highlight the idea that any science of the law is built on a philosophical system, it is dependent on an attitude in relation with the great issues of humans and humankind. That is why the thesis of the law philosophy will always serve to explaining, interpreting and implementing the positive law.

Mircea Djuvara made a distinction in principles between the knowledge of the law and its science. It is easy to notice that many citizens gather knowledge on their and their keens' rights. Such disparate knowledge is not science. There are to become science only the juridical knowledge describing real processes of the society through some general notion, some laws so that they succeed in interconnecting by some essential features: in this regard, it is not called science but a well-systematized knowledge. Consequently, "the establishment and the advance of the juridical science is not possible otherwise by mediating a juridical philosophy which any legal advisor has anyway and practices either one is aware or not of it".[6] From such considerations, Djuvara aimed, before anything else, to identify the ontological and epistemological fundamentals of the law - which represent not only the seam, the principle idea of his entire work but also the sap conferring coherency, balance and objectivity to his works.

\section{The substantiation of the juridical phenomena}

As neo-Kantian, Mircea Djuvara rejected the juridical empirics and positivism in favor of postulating the coexistence of the natural phenomena determinism and the person's freedom, which is the premise for the substantiation of the law. In the spirit of the neo-Kantian design, Djuvara considered that denying the freedom would ruin both the law and the morals. Freedom is the postulate of any matter of law; it is the fundamental of the law. Secondly, from such a position, Mircea Djuvara defined the law as having as object the acknowledgement of the rights and obligations of the outsourced social activities; thus, the law might indicate the allowed, forbidden or imposed acts in the society, based on the idea of justice.[7] The law is different from the morals, though just like the respective one has as subject the correlation between rights and obligations as it regulates only the outsourced social activities, meaning the activities achieved by facts of the society members, while the morals regulate the so-called internal for. According to him, there are two levels in the overall law: one is that of the positive law - formed of norms and rules provided by law, by the juridical custom (so-called custom), jurisprudence etc. and other is that of the rational law, which is independent of any 
relation to any norm of positive law "as we can issue judgments of law event entirely ignoring the positive dispositions; we can specifically judge the social facts only by reason, by considering the pure justice. Thus, we usually judge the deeds of men and only afterwards we search to see if they are in agreement also with the rules of the positive law. For instance, there are many times when we acknowledge a condemnable act, first we sense its injustice, judging it with our judgment, and only after, we search also to see if and how it is punished by the legal texts, the Criminal Law, the Civil Law or by other laws. We can judge by reasoning freely from the justice and even from the positive law rules; we can find out an unfair positive law. Even within the positive law framework, the legal advisor may issue many times such evaluations of injustice ... almost always the law-makers have to appeal to plain justice when drafting their rules.'[8]

Thus, the positive law is logically subordinated to the rational law. As last analysis, the rational law with its evaluations of justice will have to be one way or another at the origin of the positive law, to be the grounds for the substantiations brought to the positive law-maker - whoever this one might be. The concrete expressions of the positive law are either wrong or true, either fair or unfair, such as they are either compliant or not with the rational law. For the dispositions, judgments of the rational law become positive, it is required to add to them a certain social efficiency and a certain guaranteed requirement from the public authority; this requirement have always accompanied the positivity of the law. Thus, it results that the human being is able to issue appreciations, judgments acknowledging the justice of the social actions. All rights and obligations found that way, Djuvara considered to belong to the rational law.[9] The juridical facts - subject of the science of the law - have a rational, ideal essence. Logically, they "are anterior to any law-making, whichever would be eventually its shape and, consequently, prior to any customs and jurisprudence."[10] Even if the juridical phenomenon is purely ration, thus immaterial, this does not prevent it from being a reality influencing our daily life, conducting our activities.[11] In general, the reason is the one substantiating the experience which we have on the moral and juridical truths, highlights professor Djuvara. The essential philosophical conclusion reached by Mircea Djuvara was that it was possible to know an objective justice, valid for the reason, just like that of the realities of the nature. The implementation of the rules of the positive law is to rely precisely on it. Therefore the brutal raping, the force cannot be among the sources of the positive law. In no way, the force must not prime on the law, just the opposite, it has to be always in the service of the law. And, there are above the material facts the spiritual values - those which can establish the idea of advancement.

Consequently, the philosophy of the law should be concerned on the matter of interpreting the positive law, on the methodology of the juridical sciences, on the 
scientific understanding of the idea of justice issued rationally, on the thorough statement of the juridical values in the light of which the world should be guided. From this point of view, the philosophy of law is mostly concerned on the fundamental notions of the public law, undertaking the mission to search thoroughly the meaning the main statements, of controlling the generalizations and of attempting to unify the entire juridical science. For all these reasons, Mircea Djuvara appreciated that the philosophy of the law should become a synthetic lecture to be held at the completion of the academic studies of law [12], much more that "there is no law-maker or politician who does take a philosophy of the law. Just the same, there is no practitioner, as shy as one could be, who does not apply daily a personal juridical philosophy". [13]

\section{Specificity of the juridical knowledge}

An important matter, reprised by Mircea Djuvara, is the one regarding the nature of the juridical knowledge and the mechanism of its formation. At this thought level, Djuvara considered that the juridical ideas and knowledge (able to be integrated in the scope of the ethical ones) are distinct, even opposite to those on the nature (which Kant called "theoretical"). While the knowledge on the nature explains the phenomena regarded as objective realities, it is just the opposite with the juridical knowledge which expresses approvals and disapprovals, appeal to justifications or criticism regarding the activities of some rational beings, of some "knowledge subjects", of some persons. Explaining is always something else than justifying. The sciences on nature (physics, chemistry, biology etc.) research they study topics, they find out, they exclude the ethical values, the subjectivity; they try to explain "what it is" (Sein), to discover causes and laws, while in ethics and law, it is stated something on the topics, namely on the persons; here, it is shown "what is allowed, forbidden or imposed on persons' activity by the idea of moral wellness and of justice, either this is rational, either it is positive: a "duty", a Sollen, a devoir is stated, not a "being", a Sein, an être, ... Sein represents an indication, Sollen - an imperative". [14] Therefore, the juridical and natural knowledge compose two different worlds. We can find out in the moral-juridical world not values-means but values-purpose, meaning supreme values. The ethical commandments impose by themselves; this imperative of the mind is not imposed from outside by that sovereign law of the nature, but it is designed freely by our reason. We have to submit to the morals and justice not for achieving a superior goal to them but only for their intrinsic value."[15]

The scope of the morals and law has to involve the idea of freedom, unlike Sein world where the rigorous determinisms rules, meaning the laws, the causes etc. The law cannot address but to persons, it is produces by persons whose main attribute is the freedom. For someone to have rights and obligations, this one has to be 
considered as free person. No ethical appreciations can be issued; no juridical imperatives can be apply to anybody else than to free persons. The issue here is how a solution to the matter of the coexistence of the natural phenomena and ethical freedom coexistence can be found?

The subject point of view is creator and this involves always the idea of freedom as creation means freedom -Djuvara states. For the law, where we refer to the subjects' actions, there is no contract unless there is freedom, there is liability and no public law may exist. The ethics and law always relate to free topics while the knowledge on natural objects always refers to objects. Starting from here, we could explain ourselves why from knowing a natural reality no ethical imperatives can derive and the opposite. A Sein cannot be explained by a Sollen, or a Sollen by a Sein. In this regard, Djuvara wrote "One right or obligation is understood and explained only by another right or another obligation and never by a natural phenomenon; just the same, a natural phenomenon can be understood and explained only by another natural phenomenon and never by any person's right or obligation".[16] But, this does not mean that the two worlds are absolutely separated or parallel, as Kelsen believed. In fact, there are hierarchical relations between Sein and Sollen: basically, the juridical or moral provisions refer to real deeds carried by some persons or occurring on some things related to such actions. Thus, stating that the right can be understood without natural facts and realities is the same with stating an absurdity. The law starts by finding out or assuming such realities in order, then, to issue specific evaluations on them, according to its own criteria.

Thus, the juridical knowledge constitutes itself by an application to the moral awareness for the idea of juridical society overlaps mandatory to that of moral society and the latter to that of human society, as part of nature. The idea of justice can be acquired or issued only by comparative analysis of the social, juridical and moral realities. Djuvara concluded: the law on the establishment of juridical knowledge is namely the general law of origin for any kind of knowledge on a reality, whichever this one is. We could reach by such notions to the knowledge of some laws and causes of the juridical phenomena, to field-specific explanations. General juridical notions, and institution and rule of law cannot have but such experimental origin. Without experiences, the science of the law is not possible; but, this does not mean that positivism is the corollary of the explanations in the field of the law philosophy. Just the opposite, he did not stop long enough on the research of namely the notion of experience. That is why he did not discover, even in the nature of the experience, the existence of objective ethical and juridical values which cannot have significance other than by their application to concrete social facts which they direct and organize. The sine qua non requirements for any juridical knowledge are the juridical experience and the idea of justice. The latest is 
an absolute value conferring to each of the juridical knowledge the value of truth which they may have, being the guiding idea for all juridical knowledge.

Consequently, the juridical knowledge comprises two elements: an acknowledgement of the facts and their evaluation. Only the evaluation of the social facts would raise them to the juridical level. Related to such juridical appreciations, there is the issue if they can have objective value, implicitly if the juridical sciences are possible as cognitive disciplines. Mircea Djuvara reached the conclusion that moral and juridical judgments have objectivity and that the applications of the idea of justice may state the character of objective truth. Consequently, the juridical knowledge has the same objective value just as that of the exact sciences; what differs however is its object. And the truth of the juridical knowledge consists in their coherent, non-contradictory character, in their systematization and rational ranging. A person's action is just for its purpose, its logics, does not enter in opposition with the purposes of the other actions carried on by any other person in the same time. This way, the justice who evaluated exteriorized human actions acquired an objective substantiation, just as solid as that of the performed statements in the sciences of the nature.

In justice, the truth is coherency, by excellence; it is not something given in an absolute manner, it is not final, but it is in continuous training and improvement. In justice, the truth is coherency, by excellence; this is not something given in an absolute manner, it is not final, but it is in continuous formation and improvement. Being in relation with the referential system where it is integrated, the truth is relative and as any piece of knowledge comprises both intuitive and rational elements, a total perfection, the absolute meaning, cannot be reached. The truth of the juridical knowledge means their agreement with the requirements of the laws of logics; it involves in itself also the idea of convention as it supposes the necessary adhesion of all persons to the truth, while the error in the juridical sciences is the expression of the lack of logical harmony, of logical contradictions, the lack of adhesion. At this level, the juridical sciences meet those on the nature: both have the truth as object. The ethical Truth, the moral Good, and the Justice represent the logical arrangement of the ethical realities, such as the ethical evil represents this lack of ranging. Inside the trilogy Truth, Good and Beauty, the predominant one is the Truth, the value of all values, the main condition for the establishment of Justice.

\section{The connections between the law and morals}

An interesting contribution brought by Mircea Djuvara to the development of the law philosophy targets the relations between the law and the morals. He considers that our judgments on the rational value of the activities may be of moral and juridical order. When the activity is purely interior, meaning an intention, a feeling, 
a trend etc. we are in field of morals; just the opposite, any exteriorized action, expressed by a material gesture of the agent in relation with its keens enters in the field of law and may, depending on the circumstances, turn into positive law. In morals, the judgment is made on an interior act, thus it is the agent's subjective purpose which has to be the good itself, while, for the law, the judgment is made on the exteriorized action in its entirety, including on its purpose; therefore, this act, in its totality and objective finality, has to establish the justice.[17]

The deep root of the law and of the morals has to be found in act of objective reasoning, presuming the idea of freedom on one hand and that of the need for logical laws, on the other. These two aspects represent the idea of law and the other the idea of obligation which we are going to find in the field of ethical and juridical realities. The idea of rational necessity of the truth comprises the germs of the idea of mandatory sanction. Both moral and juridical knowledge having as object the rights and obligations are fundamentally different from the knowledge in the sciences of the nature as the obligations are not the expression of a natural causal need. The obligations are designed by their nature to being violable and they appear to us as prescriptions which we understand to comply with in our real activity.

Therefore, the law cannot be split by the morals; any juridical statement opposite to it would be nothing else but an error. The law and the morals, having same roots, do not make possible the design that an ideal justice could be immoral, just as we could not think of the morals being unjust. However, when it happens to occurring incongruences between certain provisions of positive law and certain moral ideas, these are to be due to the fact that the effective social regulations did not prescribe certain details which prove to be faulty. Ideally, any moral action is just, just as any exercise of a juridical fact has to be moral, if it is true that the law and the force must not be confused in principle. In all cases, any law supposes certain morals. Thus, "any organization in the public law cannot indeed find another justification but a common moral ideal. There cannot exist in the private law just norm in opposition with the morals and all civilized legislations experience this moral ideal in their texts. At its turn, the criminal law would be a monstrosity if opposed to the morals. The advance of the international law tends to harmonizing with the moral ideal of the civilized humankind. Finally, the juridical freedom, in general, in an organized society, freedom without which the law would not be possible, it is basically nothing else but the freedom to carry on a moral activity: Without this ground, it would lack any other superior justification."'[18] It is one of the hugest errors to think that the juridical order limits the freedom. No the freedom as such, but the unjust one, the abuse of freedom are limited by the juridical order - claim justified Djuvara. 
The specificity of the law is also highlighted by its purpose. According to Djuvara, this would consist in establishing the justice which is categorical and not hypothetical imperative, imposed by our reason; it is the progressive development of the spiritual values aimed by persons' free activity. Justice and law are the external guarantee of the moral activity. The justice is the supreme value in the juridical hierarchy. Other purposes cannot be substitute to it, either they are the "usefulness", the "social solidarity", the "society preservation", the "social harmony", the "social progress" etc. - as it has been tried to be done during the millennia of law philosophy. The social values may be considered as purpose of the law in the situation when they identify with the supreme values of the spirit, when they appear as ethical values, composing the guiding idea of the social system. After all, the ultimate purpose of the law has to be the moral development of each person by the free activity of the creating spirit. The material common welfare is nothing but a mean, and not a purpose. The law exists by justice in favor of the State and, in the same time, in favor of the individual; the State and the individual must be regarded as distinct legal persons, but not antinomy ones; the State exists for the individuals and the individual for the State. Moreover, the law imposes to the persons on behalf of the justice. If the positive law is to be imposed without justice on humans, it would be nothing else but a plain strike of force. In order to be a positive law, the norms imposed to a society are to be acknowledged as just. As supreme value, the justice does not float in void. It materializes through the juridical norms which are to be applied to humans' deeds and needs resulting so the social order, the juridical body of the national society which is the just State. There is no justice without social order.

To conclude with, the law and the morals are tightly correlated, completing each other. The juridical and ethical knowledge have the same logical structure and are parallel with the information belonging to the sciences of the nature. But the moral is the one dominating the law. In this idea, there cannot be a rule of conduct compliant with the justice which, in the same time, is not also compliant with the morals. The technique of drafting and issuing the positive law seems to be indifferent to the relation to the moral values and to the supreme idea of justice, but, in reality, it is fundamentally oriented or, at least, "allowed" by the great values of Man: the Good and the Justice. Any juridical reality comprises a directive of thought corresponding to the idea of law or of justice and applied to the positive norming of the changing phenomena of the social life. Thus, the law establishes the formal requirement of the current social activities. Basically, the idea of justice is a method to harmonize, with rational coherency, the purposes of the persons' exteriorized actions, while the idea of the moral good is a method of logical harmonization of the internal purposes of the same actions. 
6. The specificity of the juridical norms, the idea of justice and equity

Mircea Djuvara analyzed the specificity of the law also starting from the comparison of the appropriate reality layers of the sciences which it studies. Each science from the famous Comte ranking (he ranked them by the criterion of the increasing complexity of their object and historical succession) studies a field of the reality in connection with the others and having, in the same time, a specificity. Thus, the field of study of the biology is the world of living, of the psychology is the life of the soul, of the sociology is the society, and of the law is the correlation between rights and obligations. In its explanations, the science of the law needs the knowledge from the other sciences, but it will also comprise additional specific elements both at informational and methodological layers. Thus, for instance, the science of the law capitalizes the notions of sociology, but it could not limit itself to it as it comprises normative items, the idea of justice which does not exist in sociology.

As social reality and compared to the extra-social universe, the specificity of the law would consist of: 1) the laws of nature are inviolable, while the norms of morals and law are violable by their own nature; 2) the phenomena of nature cannot be submitted to the law except for the measure when they can be put in relation with the activity of the persons in the society; 3) a juridical norm cannot have as object the impossible; 4) the juridical and ethical norms are not abolished by the deeds they violate. These elements revealing the specificity of the law are at the origin of the special way of knowledge used in the juridical sciences: within it, there are performed operations not only with judgments of acknowledgment like in the natural sciences, but also with value judgments (of evaluation).

Regarding the correlation rights-obligations-constraints, the juridical sciences are different from other branches of the knowledge studying a similar referential: the morals, for instance. Unlike the moral obligations and constraints, the juridical ones have from the very beginning a negative character of abstention, as the law refers to the external actions, while the morals refer to those related to individual's persuasions, intentions and aims. If in morals, each one may have obligations towards itself; this could not be possible in law: here, a person's obligations are towards others. The same goes for the sanctions as well, though deriving from the exigencies of the reason; the juridical ones will not apply to the internal moral forum, but only to the external facts by the systematic intervention of the State specialized bodies. This way the justice and the law must regulate, rule the external human activities, subordinating themselves to the moral values. The ultimate purpose of the law must be the moral development of each one by the free activity of the creator spirit. Justice and law are the external warranty of the moral activities. Outside justice and fairness, the law may have no meaning; it will present 
itself to us as a mean of humans' torture and not as a mean of peaceful cohabitation for all, an optimal form of achieving the social order.

But, the idea of justice comprises also that of fairness as the ideal of justice could not, nor it could be ever achieved in a perfect, accomplished shape. Often, it may occur to reach genuine unjust situations by the implementation of the legislation due to the generality of the law, to the consequences drawn by the laws and even of some erroneously drafted law provisions. Though, it was aimed to achieve justice, in the end, by applying the law, the results were bad, unfair. We find here a profound Djuvara's observation on the antinomy which may occur in the work of the legal experts, namely: substantiating the general laws on certain concrete events, the experts aim to achieve justice, but this purpose would not be reached certainly due to the generality of the laws which, sometimes, may remain behind the real social life. Such a contradiction between the law and social reality could be solved only by rectifying the laws, by practicing the laws depending on the concrete situation of applying them - which has often been assigned with the term of fairness in the history of the law philosophy (Plato, Aristotle, Kant etc.). The putting into practice of the principle of fairness comes to improve the law according to the requirements of the moral values. Going above the antinomy is yet possible, according to Djuvara, by completing the justice with fair measures, so the injustice disappears. But this means rectifying the law itself with moral solutions applied to the situations submitted to regulations. Under such terms, the state expresses itself as consecrated body, of eventual creation and application of the positive law in order to achieve the idea of justice.

\section{Conclusions}

The previous theoretical explanatory endeavor proves the way how a great Romanian scholar imposed the Romanian philosophy of the law in the European circuit by an extremely fecund work, by very clear and solid substantiations. By its value and contemporaneity, Djuvara's philosophical concept went beyond its age; it proposed new standards of reference in the modern age, while exerting an auspicious influence on the Romanian School of Law, especially during the last decades. Not accidentally, the renowned Italian philosopher Giorgio Del Vecchio considered Djuvara as one of the greatest contemporary thinkers in the philosophy of the law.

In the end, we have to highlight the actuality and usefulness of Djuvara's essential ideas on the rational substantiation of the law, on the autonomy of the moral and juridical consciousness, guiding juridical values of the historical dynamics of the law: the juridical truth, the justice and fairness, the philosophical substantiation of the law-making power, the theory of the juridical knowledge, and, not lately, the principles of the democracy. 
As political being, Djuvara put into practice these ideas, being convinced that the achievement of justice requires responsible and competent political elite, a political leadership based on mutual and constant connections between those who are led and the leaders. He considered that the politics cannot be untied from the juridical power, but it is the highest form of the juridical as it subordinates itself to the living idea of justice. [19] All these ideas are part of the juridical-political culture of the democracy, being necessary and useful, nowadays, for the improvement of the democratic institutions not only at national level, but also at the level of the European Union.

\section{References}

1. Bagdasar, N., „Filosofia dreptului”, in „Istoria filosofiei”, vol. V, „Filosofia românească de la origini până în prezent", by N. Bagdasar, T. Herseni, and S.S. Bârsănescu, Bucharest: The Romanian Philosophical Society, 1941, pp.290-310.

2. Culic, Nicolae, „Mircea Djuvara, teoretician şi filosof al dreptului (studiu introductiv)”, in Mircea Djuvara, "Eseuri de filosofia dreptului", Bucharest: Ed. Trei, 1997.

3. Djuvara, Mircea, „Analiza ideii de convenţie în drept”, Bucharest: Editura Academiei Române, 1939.

4. Djuvara, Mircea, „Contribuții la teoria cunoaşterii juridice”, in“Eseuri de filosofie a dreptului”, Bucharest, Ed. Trei, 1997.

5. Djuvara, Mircea, „Despre autonomia conştiinţei morale şi juridice”, Bucharest: Tipografia Mişcarea, 1938.

6. Djuvara, Mircea, „Eseuri de filosofia dreptului”, Bucharest: Editura Trei, 1997.

7. Djuvara, Mircea, "Faptele şi Dreptul: Natura cunoaşterii juridice şi mecanismul formării ei", in "Eseuri de filosofie a dreptului", Bucharest, Ed. Trei, 1997.

8. Djuvara, Mircea, „Filosofia domnului Gherea. Le moi et le monde” (Essai d'une cosmogonie antrophomorphique), Bucharest: The Romanian Philosophical Society, 1939.

9. Djuvara, Mircea, "Precis de filosofie juridică", în "Eseuri de filosofie a dreptului", Bucharest, Ed. Trei, 1997.

10. Djuvara, Mircea, „Puterea legiuitoare”, in the vol. „Constituția din 1923 în dezbaterea contemporanilor”, Bucharest: Editura Humanitas, 1993, pp.143-147.

11. Djuvara, Mircea, „Teoria generală a dreptului. Drept raţional, izvoare şi drept pozitiv”, Bucharest: Editura All Beck, 1999.

12. Djuvara, Mircea, „Fundamentul fenomenului juridic. Reflecţii asupra principiilor logice ale cunoaşterii juridice", translated by Roxana Albăstroiu, Foreword and Introductory Study Dan Sfârnă, Craiova: Aius, 2014.

13. Giorgio Del Vecchio, "Lecţii de filosofie juridică", Ed. Europa Nova, Bucharest.

14. Piuitu, Dumitru-Viorel, „Filosofia juridică a lui Mircea Djuvara”, Craiova: Sintech, 2006.

15. Popescu, Dragoş, „Fundamentul fenomenului juridic la M. Djuvara”, in „Istoria logicii româneşti”, coord. A. Surdu and Dragoş Popescu, Bucharest: Editura Tehnică, 2006, pp. 700- 706.

16. Speranţia, Eugeniu, "Introducere în Filosofia Dreptului", Sibiu, 1944. 


\section{Notes}

[1] See N. Bagdasar, „Filosofia dreptului” (Philosophy of the Law), in „Istoria filosofiei” (History of the Philosophy), vol. V, „Filosofia românească de la origini până în prezent” (Romanian Philosophy from the Origins to Our Days), by N. Bagdasar, T. Herseni, and S.S. Bârsănescu, Bucharest: The Romanian Society of Philosophy, 1941, p.289.

[2] Giorgio Del Vecchio, "Lectii de filosofie juridică" (Lessons of Juridical Philosophy), Ed. Europa Nova, Bucharest, p. 166.

[3] Eugeniu Speranţia, "Introducere în Filosofia Dreptului" (Introduction in the Philosophy of Law), Sibiu, 1944, p. 260.

[4] Djuvara's philosophical writings belong to several philosophical branches among which: the history of philosophy, ontology, theory of knowledge, logics, ethics and methodology. He proves in the performed analyses a thorough mastering of the great trends of classical and contemporary ideas, referring to works of some great modern and contemporary thinkers such as: Descartes, Locke, Kant, Fichte, Hegel, J. St. Mill, Bergson, W. James, Husserl, Nietzsche, Lichtenberg, Carnap, Spaier, Rickert, H. Poincare, E. Boutroux etc.

[5] Mircea Djuvara, "Precis de filosofie juridică" (Compendium of Juridical Philosophy), in "Eseuri de filosofie a dreptului" (Essays of Law Philosophy), Bucharest, Ed. Trei, 1997, p.179.

[6] Idem, p. 180.

[7] Idem, p. 180.

[8] Idem, p. 181.

[9] A very concise analysis in this regard is performed by Popescu, Dragoş. See „Fundamentul fenomenului juridic la M. Djuvara” (Basis for the juridical phenomenon at M. Djuvara), in „Istoria logicii româneşti” (History of the Romanian Logics), coord. A. Surdu and Dragoş Popescu, Bucharest: Editura Tehnică, 2006, pp. 700- 706.

[10] M. Djuvara, „Fundamentul fenomenului juridic. Reflecţii asupra principiilor logice ale cunoaşterii juridice" (Basis of the Juridical Phenomenon. Considerations on the Logical Principles of the Juridical Knowledge), Craiova: Aius, 2016, p. 66.

[11] Idem, p.67.

[12] Mircea Djuvara, "Filosofia dreptului în învăţământul nostru juridic" (Philosophy of the Law in Our Juridical Education), in cited tome, p. 138.

[13] Idem, p. 140.

[14] Mircea Djuvara, "Faptele şi Dreptul: Natura cunoaşterii juridice şi mecanismul formării ei" (Facts and Law: Nature of the Juridical Knowledge and the Mechanism of Its Formation), in cited tome, p. 185.

[15] Idem, p. 186.

[16] Idem, p. 192.

[17] Mircea Djuvara, "Drept şi moralŭ" (Law and Morals), in cited work, p. 60.

[18] Idem, pp. $62-63$.

[19] See M. Djuvara, „Contribuţii la teoria cunoaşterii juridice” (Contributions to the Theory of the Juridical Knowledge), in cited paper, pp. 318-319. 